\title{
A Study of the "The System of Military Titles "in the Early Han Dynasty
}

\author{
Meihwa, Zhou ${ }^{1, *}$ Minhwa, Zhou ${ }^{2}$ \\ ${ }^{1}$ College of Literature, Huanggang Normal University, Huanggang, Hubei, China \\ ${ }^{2}$ College of Literature, Huanggang Normal University, Huanggang, Hubei, China \\ *Meihwa, Zhou.Email:1632036252@qq.com
}

\begin{abstract}
A macroscopic study of The System of Military Titles must see the important value of The System of Military Titles formed in the process of implementation. Liu Bang made use of The System of Military Titles to resolve two major crises in a row and finally stabilized the political situation. Since then, the importance of The System of Military Titles has been enhanced. The political and economic interests enjoyed by the people in the Han Dynasty were all based on The System of Military Titles, not on the official position. The rich funerary objects of M147 in tushantun, Shandong Province, are the best proof of the military merit system.
\end{abstract}

Keywords: History of Qin and Han Dynasties, The System of Military Titles, The Statutes and Ordinances of the Second Year, Liu Bang, Tushantun M147

\section{INTRODUCTION}

After seven years of fighting, Liu Bang finally took the throne of emperor in the fifth year of the Han Dynasty (202BC). However, his throne was not stable, and several crises appeared one after another, which made the Han Dynasty almost perish. First of all, the people in Guanzhong did not want to recognize the new emperor, and most of them hid in the mountains. Secondly, in the sixth year of the Han Dynasty (201BC), a group of soldiers who followed Liu Bang to fight in the world, but did not get a reward, all sat in the Luoyang palace to prepare for rebellion. In order to resolve the two crises, Liu Bang can only use The System of Military Titles, not only to attract the people in Guanzhong to return to their hometown, but also to satisfy the soldiers who are ready to rebel and be willing to be loyal to Liu Bang. The reason why the "The System of Military Titles" can play such a great role is that it is The System of Military Titles that is the most important key to people's prosperity in the Qin and Han Dynasties. In the Qin and Han Dynasties, it was not the official position, but The System of Military Titles. This can be fully displayed in a grave of high rank.

\section{LIU BANG USED THE SYSTEM OF MILITARY TITLES TO RESOLVE THE CRISIS}

\subsection{Attract People from Guanzhong to Return to Their Hometown}

After Xiang Yu was eliminated and the world was unified, Liu Bang ascended the throne of emperor in Dingtao, Shandong Province. Although Liu Bang became emperor, he had to face how to pacify the people and stabilize the soldiers and generals who followed him. The most surprising thing is that the laws of the Qin Dynasty are very strict, but the people living in Guanzhong, the capital, are willing to be people of the Qin Dynasty, and they are not willing to accept the fact that the Qin Dynasty perished. Therefore, they hide in the mountains and are not willing to be people of the Han Dynasty. This made Liu Bang very upset. So on May 5 the fifth year (202BC), he issued an edict: "some people in the past had been hiding in the mountains and grass, and no registered residence. Now the world has settled down, so that they can all return to their hometown."

But what can we do to attract them back home? Liu Bang said: "they were all from the Qin Dynasty. They had titles in the Qin Dynasty, and they also had land and houses because of titles. As long as they are willing to return to their registered residence, they can retain their title, field and house [1] in the Qin Dynasty. This edict is very attractive, because land and houses are the most basic guarantee for everyone's survival. The reason why the people in Guanzhong prefer to hide in the mountains rather than become people of Han Dynasty is that they don't want to lose these titles, houses and fields. They don't care who will be the emperor at all, they only care about their living conditions and whether the honour and wealth given by the Qin Dynasty can be preserved. After Liu Bang understood the ideas of the people in Guanzhong, he immediately changed his original Chu Jue system into Qin Jue system, [2] and the people's titles, fields and houses in Guanzhong could be completely preserved. After seeing the decree, the people of Guanzhong quickly descended and returned to registered residence.

In order to attract the people of the Qin Dynasty to return, Liu Bang made special use of the The System of 
Military Titles implemented by the Qin Dynasty, so that the people with nobility could keep the fields and houses granted to them by the Qin Dynasty. This means that: the title is very attractive to the common people, because as long as you have a title, you not only have a secure life, but also a more noble status than others, and you can enjoy legal privileges. Therefore, the people of the Qin Dynasty in Guanzhong worried that the Qin Dynasty would perish and their titles would not be preserved.

In addition, in this imperial edict, Liu Bang only mentioned the issues of titles, land, housing, and so on. He did not mention official positions at all, because official positions only get wages, not houses and land, nor legal privileges. These rights and interests can only be enjoyed by the people if they get the title. Therefore, Liu Bang will never use official positions to attract people. He only uses the title of nobility to attract people, and the people will come back to register their registered residence.

\subsection{Stop the Generals Preparing to Rebel in Luoyang}

In the sixth year of the Han Dynasty, Liu Bang had already awarded more than 20 meritorious officials, but there were still many soldiers who had not been awarded titles. These soldiers had been quarrelling with each other all the time, comparing who was more meritorious, because the greater the merit, the higher the title. Liu Bang felt annoyed when he saw it, so he stopped talking about merit for the time being. However, Liu Bang stopped sharing rewards, which aroused strong dissatisfaction among the soldiers. One day, when Liu Bang was in the south palace of Luoyang, he saw many soldiers sitting on the ground talking about things. Liu Bang asked his counsellor Zhang Liang, "What are they doing?" Zhang Liang replied, "doesn't the emperor know? They are going to rebel Shocked, Liu Bang said to Zhang Liang, "now that the world is stable, why do they want to rebel?" Zhang Liang replied: "you were still the common people at that time, and you can only become emperor now because these people helped you fight. But the meritorious officials you awarded, Xiao He and Cao Sheen, are your old friends. All you kill are the people you hate the most. They are afraid that you will not be able to confer titles according to their merits, nor will you confer the land of the whole country on them, and that you will be killed because you have offended you before, so they all gather here to discuss and conspire against each other."

Liu Bang was worried and asked Zhang Liang what to do? Zhang Liang said, "Who does the emperor hate the most?" Liu Bang said: "Yongchi, I have a grudge against him. I used to be very down-to-earth. He humiliated me many times. I just wanted to kill him, but because he made so many contributions, I couldn't bear to kill him." Zhang Liang said, "Please give the emperor the title of Yongchi first. When you see that all the people you hate most are awarded, you will not be suspicious of the emperor any more. [3] " Liu Bang then set up a banquet to invite the officers and men to dinner, and awarded Yongchi the title of "Shi Fang marquis", which can collect 2500 households' taxes[1], and ordered the prime minister to quickly calculate everyone's credit, and then give the reward.

Liu Bang awarded a total of 143 "chehou", which is the highest rank among the 20 ranks of military nobility (the 20th rank). In addition, Liu Bang awarded 113 "Guannei Marquis", which is the second highest rank among the 20 ranks (19th rank). "Chehou" has its own territory, can decide who to be an official, and can also collect taxes from the people. "Guanneihou" does not have his own land, but the emperor will grant him 95 hectares of land and 95 units of houses. [4]

After Liu Bang awarded these officers and soldiers, he also wrote a certificate: "even if the Yellow River becomes a small belt and Mount Tai becomes a small stone, your vassal state will exist forever, and your descendants can inherit it forever. [1] "The title can be passed on to the descendants, which means that the honour and wealth gained by the title can be passed on all the time. Of course, the officers and men were very happy and did not want to rebel any more.

\subsection{The Greatest Benefit of a Title}

The two year laws and regulations unearthed from the Han Tombs in Zhangjiashan, including the household law, recorded the amount of land and houses that could be owned after obtaining the title. Wang Yanhui has made statistics and listed the following chart: [5]

Table 1. The number of fields and lands acquired by 20 titles

\begin{tabular}{|c|c|c|c|c|}
\hline Rank of titles & Title of title & fields & house & Today's square meters \\
\hline 20 & Chekhoo & & 105 & 179966 \\
\hline 19 & Guannei Marquis & 95 hectares & 95 & 162826 \\
\hline 18 & Great commoner & 90 hectares & 90 & 154256 \\
\hline 17 & Si Che Shu Chang & 88 hectares & 88 & 150828 \\
\hline 16 & Dachangzao & 86 hectares & 86 & 147401 \\
\hline 15 & Shao shangzao & 84 hectares & 84 & 143973 \\
\hline 14 & You Geng & 82 hectares & 82 & 140545 \\
\hline 13 & Zhonggeng & 80 hectares & 80 & 137117 \\
\hline 12 & Zhuo Geng & 78 hectares & 78 & 133689 \\
\hline
\end{tabular}




\begin{tabular}{|c|c|c|c|c|}
\hline 11 & You Shu Chang & 76 hectares & 76 & 130261 \\
\hline 10 & Zon Shu Chang & 74 hectares & 74 & 126833 \\
\hline 9 & Wu Daifu & 25 hectares & 25 & 42849 \\
\hline 8 & Gongsheng & 20 hectares & 20 & 34279 \\
\hline 7 & Gong Daifu & 9 hectares & 9 & 15426 \\
\hline 6 & Gung Daifu & 7 hectares & 7 & 11998 \\
\hline 5 & Daifu & 5 hectares & 5 & 8570 \\
\hline 4 & Bouguerin & 4 hectares & 4 & 6856 \\
\hline 3 & Zhan Niao & 3 hectares & 3 & 5142 \\
\hline 2 & Shangzao & 2 hectares & 2 & 3428 \\
\hline 1 & Gongshi & 1.5 hectares & 1.5 & 2571 \\
\hline
\end{tabular}

This is the amount of land and houses that Liu Bang and empress Lu were able to obtain for the 20 rank titles. There has never been an era in Chinese history in which so much land and houses could be obtained. In order to buy people's hearts and hope that the people would accept their regime, Liu Bang and empress Lu used The System of Military Titles to plan the amount of land and houses that each rank could get. In this way, we can understand that only when we get a title can we be prosperous, not an official. Therefore, Liu Bang must draw The System of Military Titles to win the people in Guanzhong to return to register the registered residence. To let the soldiers abandon their rebellion, Liu Bang also use military nobility to bestowing their duty instead of using official positions. Because being an official can only get wages, not such a large number of land and houses, nor legal privileges. Of course, people only want to get titles, and they don't care about official titles.

M147 is the tomb of Liu Ci, the uncle of Emperor $\mathrm{Wu}$ of Han Dynasty. Liu Ci was a nobleman of the Liu family, and his status was higher than that of Chehou, but he was also the magistrate of Xiao County. The objects buried in his tomb are very rich and exquisite, including Jade mats (Fig. 1) [6], Jade Wenming (Fig. 2) [7], etc. This is definitely not the economic condition that a county magistrate with an annual salary of 600 to 1,000 stone (one stone $=120 \mathrm{Jin}$ ) can have. This is the rich financial resources that can be obtained only by having one's own vassal state, collecting taxes from the vassal state, or receiving special rewards from the emperor.

When Shang Yang designed this Military nobility system, he had emphasized: "we should clearly distinguish the rank of titles, so that everyone's fields, houses, servants, clothes, etc. should be distinguished according to the rank of titles." The military nobility system was designed by Shang Yang. He planned the honour and wealth that everyone could enjoy according to the rank of titles, not according to the rank. This is the biggest difference between the military nobility system and the "five rank nobility system" of the Zhou Dynasty. It is also a brand-new system that allows the people to obtain titles because of military merit.

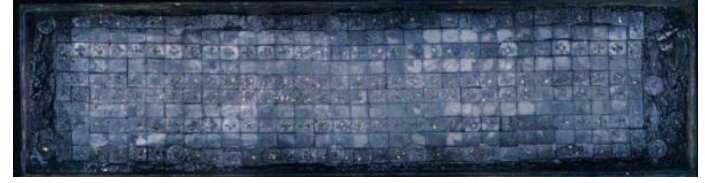

Figure 1 Jade mats

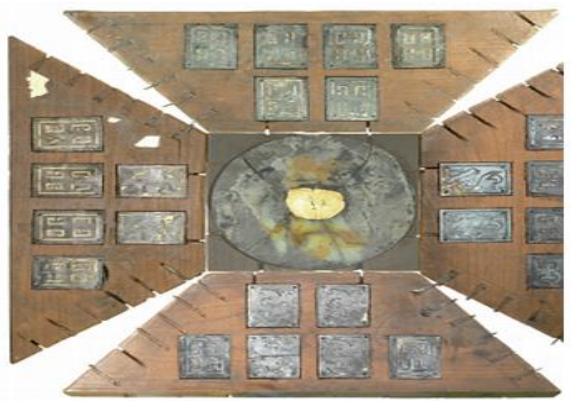

Figure 2 Jade Wenming

\section{CONCLUSION}

In the past, other scholars' research on The System of Military Titles only focused on the rights and interests of The System of Military Titles and other aspects of the system history. From the perspective of macro social and political history, this paper aims to see The System of Military Titles's handling of the problem of Liu Bang's respect for the throne, and to resolve the crisis of a group of soldiers preparing to rebel. From then on, the Han Dynasty paid more attention to the rights and interests of military merit system than the Qin Dynasty. We can see clearly from the rich burial objects of Han tomb 147 in tushantun that the burial system of the Han Dynasty was based on The System of Military Titles, not on the official position. We can know that The System of Military Titles had a great influence on the Han Dynasty. The System of Military Titles made a great contribution to the political stability of the whole Han Dynasty

\section{ACKNOWLEDGMENTS}

This paper is the phased achievements of the Doctoral Fund Project " An important weapon in the early days of the implementation of the law -- the role of military merit and nobility system (from Liu Bang to empress Lu as an example)" (2042020002) of Huanggang Normal University. 


\section{REFERENCES}

[1] Ban Gu (32-92), Hanshu, Zhonghua Book Company, Beijing.

[2] Zhu Shaohou(1926-), , Commercial Press, Beijing.

[3] Sima Qian (145BC- ? ), Shiji, Zhonghua Book Company, Beijing.

[4] Zhangjiashan Bamboo Slips sorting group, The Statutes and Ordinances of the Second Year, Cultural Relics Publishing Housey, Beijing.

[5] Wang Yanhui, Han bamboo slips in Zhangiiashan and the society of Han Dynasty, Zhonghua Book Company, Beijing.

[6] Pengyu, What happened to the county magistrate family in the Han Dynasty. Popular Archaeology, vol. 2, 2018, pp.52-60.

[7] Qingdao Municipal Institute of Cultural Heritage Conservation and Archaeology and Huangdao District Museum, The excavation of mound No.4 and burials of the Tushantun cemetery in Qingdao, Shandong. Journal of Archaeology, vol.3, 2019, pp. 52-60. 